\title{
OPERNÉ MULTIMÉDIÁ STŘEŽENÉHO PARNASSU
}

„Každá opera smeruje k mýtu,“ napísal r. 1972, tesne pred svojou smrt'ou, skladatel', dirigent a hudobný teoretik René Leibowitz a zdá sa, že jeho tvrdenie je aktuálne aj vo veku digitálnych interaktívnych technológií. Ale tak, ako sa na nepoznanie zmenili estetické a poetické konvencie operného žánru, aktualizovali sa aj naše mýty a mytémy. Nielen umeleckým dielom ale aj mýtom sa dnes môže stat' naozaj čokol'vek, a zrejme to tak bolo vždy. Vel'mi múdro to formuloval už semiológ Roland Barthes: „Mýtus je promluva, a proto mýtem může být vše. Mýtus podléhá pravomoci diskursu. Nedefinuje se předmětem svého sdèleni, ale tím, jakým zpưsobem toto sděleni vyslovuje: existuji formální meze mýtu, nikoli však meze substanciální. Mýtem tedy může být vše? Ano, jsem o tom přesvědčen, nebot' univerzum skýtá neomezený počet možností. Každý predmět na světě může přejít z uzavřené, němé existence do orálního stavu, otevřeného přisvojeni ze strany společnosti, protože žádný zákon, at’ už přirozený či jiný, nezakazuje mluvit o věcech. [...] Některé mýty jsou velmi staré, ale žádné nejsou věčné; prechod od skutečnosti k promluvě totiž zajištuji lidské dějiny a jedině tyto dějiny vládnou nad životem a smrti mytické reči. Mytologie, at' dávná či nedávná, může mít pouze historický základ, nebot mýtus je promluvou vyvolenou dějinami: nemůže se vynořit $z$, přirozenosti 'věci. “"

Nová doba má pochopitel'ne nových hrdinov, nové legendy a nové príbehy. Operné hviezdy dnes na javiskách či televíznych obrazovkách stvárňujú vedcov, podnikatel'ov, politikov, športovcov, mediálne hviezdy, a dokonca aj sektárov a teroristov. Námetom pre operné libreto môže byt' návšteva amerického prezidenta v Č́ne v časoch studenej vojny (John Adams: Nixon in China, 1985-87), teroristický únos na Blízkom východe (John Adams: The Death of Klinghoffer, 1990-91), súdne pojednávanie s členmi nebezpečnej sekty (John Moran: The Manson Family, 1991) alebo vít’azstvo českých hokejistov na olympiáde (Martin Smolka - Jaroslav Dušek: Nagano, 2001-03). Periskop libretistov akoby strácal historickú híbku. Ich príbehy sa čoraz zriedkavejšie odohrávajú vo vzdialenej minulosti a ked' už áno, je to minulost' dištancovaná nielen umeleckým jazykom 
ale aj cez prizmu médií a interpretačných nánosov. Rovnako ako pre literátov či filmárov, aj pre autorov operných libriet ja zaujímavá najmä aktuálna prítomnost', vrátane mediálnych manipulácií, ktoré sa podiel'ajú na vytváraní jej obrazu. Médiami sprostredkované dejiny dnes ,vládnou nad životem a smrtí mytické reči.“" Mení sa aj civilný status archetypálnych charakterov tradičných opier, a tak Dionýza reprezentuje kultová rocková hviezda (Harry Partch: Revelation in the Courthouse Park, 1960), Oidipom môže byt' znechutený nezamestnaný mladík z londýnskeho East Endu (Mark-Anthony Turnage: Greek, 1988) a boh Hermés vystupuje ako scatujúci vlakový sprievodca na trati v oblasti mississippskej delty (Anne LeBaron: The E. \& O. Line, 1993).

V novodobých operných dielach však nie sú nové iba literárne, hudobné a scénické metódy ale aj médiá a technológie, ktoré sa v nich uplatňujú. Dobovým aktualizáciám v sujetovej rovine zodpovedajú trendové inovácie v oblasti média a vzájomná súčinnost' obidvoch aspektov spôsobila, že sa porenesančné intermédiá zmenili na postmoderné multimédiá. V českom kontexte môžu byt' príkladom tejto premeny (i recepčných problémov, ktoré ešte stále $\mathrm{v}$ konzervatívnych kruhoch spôsobuje) zdanlivo provokatívne inscenácie brnianskej agentúry Střežený Parnass $^{\mathrm{TM}}$ (Zdenek Plachý a Jiří Šimáček). Podl'a kontroverzných recenzií v tlači by sa mohlo zdat', že provokácia je hlavnou stratégiou a výstrednost' hlavnou poetickou maximou združenia. Nie je to však také jednoznačné a domnievam sa, že estetická a umelecká hodnota ich diel pretrvá aj v budúcnosti, ked’ provokatívnost' a výstrednost' stratia punc dobovej aktuálnosti. Autorský tandem Plachý-Šimáček síce zámerne prekračuje nejasné a pohyblivé hranice medzi „vysokým“ umením a „nízkou“ populárnou kultúrou obidvomi smermi a porušuje nepísané tabu písaných i nepísaných pravidiel žánrov, no robí to s nadhl'adom, v primeranom umeleckom stvárnení a vôbec nie na úkor originality a kvality či v záujme lacnej senzácie. Ich diela sú výstižné reprezentácie doby, ktorá je sama kontroverzná najmä tým, že zahmlieva realitu technologicky generovanými simulakrami. A práve rozmanité podoby iluzionizmu a mediácie našli uplatnenie v poetike Střeženého Parnassu.

Tradičné operné prostriedky a zauživané mytémy a symboly bývajú v ich scénických dielach postmoderne dištancované aktuálnym médiom, cez humornú optiku a v dialógu s tradíciou. V Áriách k nezaplacení (2002; Zdenek Plachý, Jiří Šimáček a hans w. koch), napríklad, je mýtoetymologické vzývanie anjelov počas špiritistickej seansy prerušované drzou videokamerou jedného z japonských host'ov, pre ktorých žánrový obrázok z rudolfínskej Prahy zinscenovala agentúra Střežený Parnass ${ }^{\mathrm{TM}}$ ako súčast' svojho najnovšieho kultúrno-obchodného produktu - podnikového karaoke večierku operných árií. Protagonistov scény - cisára Rudolfa II., dvorného polyhistora Johna Dee, jeho manželku Jane a asistenta pre komunikáciu s anjelmi, magistra Edwarda Kellyho - snímanie kamerou očividne neruší. Zaneprázdnení transcendentálnym zážitkom, nevenujú pozornost' ani povahe komunikačného média. Vôbec ich nevyvádza z miery, že je ním televízna obrazovka. Chladné, autoreferenčné mcluhanovské médium zvestuje účastníkom seansy nekompromisný odkaz bohov: „Chcete-li znát víc, dejte nám víc 
zlata!“ Priamočiarost' „duchovného“" posolstva anjelov je omračujúca; ved’ kto by netúžil poznat' viac $\mathrm{z}$ tajomstiev nadprirodzeného sveta a zároveň mat' viac zlata. Zákernost' dilemy spočíva $\mathrm{v}$ miere, kol'ko zlata sme ochotní pre poznanie obetovat' a či vôbec nejaké. Zlato má podobu zlatých náramkových hodiniek, pochopitel'ne s vyrytým firemným logom a venovaním od šéfa japonskej materskej spoločnosti. Do deja ich vovádzajú šarmantní moderátori večera (reálne tváre a hlasy, známe z komerčných elektronických médií), sl'ubujúc ich ako odmenu pána Akiru za najpresvedčivejší spevácky výkon vel'kej karaoke hry. Št’astným výhercom sa stáva pán Milan po tom, čo pred „prázdnym orchestrom“ (doslovný preklad japonského pojmu ,karaoke“) oduševnene predvádza výstup regrútov z Janáčkovej Jeji Pastorkyně i dueto Věrné naše milování zo Smetanovej Prodanej nevěsty. Za výkonom vít'aza nezaostávajú ani čísla ostatných sút'ažiacich - Dvořákov Vodník v podaní pána Richarda, Libuša pani Marty, Rusalka pani Gabriely, ária $O ́$ vy lípy zo Smetanovej Libuše v podaní pána Ondřeja a najmä Čurymuryfuk! z Dvořákovej Rusalky v temperamentnom stvárnení pani Věry. Defilé postáv a highlights z českej opernej klasiky sa odohráva pred neviditel'ným elektronickým orchestrom (autorom úprav árií pre karaoke je Martin Burlas) a pod výpravnou videoprojekciou z japonských mediálií, adjustované konverzačnými klišé moderátorskej dvojice, skandovaním štatistov, vystúpením zápasníkov sumo i nečakanou zápletkou, spôsobenou rozdielnym chápaním spoločenského statusu ženy v tradicionalistickom Japonsku a emancipovanej Európe. Skrátka show aká má byt': štylizovaná, účelovo generovaná zábava, pozdvihnutá na úroveň snobského intermédia priamo v historickom svätostánku najvyššej, tradíciou posvätenej umeleckej kultúry.

Tuctová show, ako ju poznáme z televíznych obrazoviek, ktorú smelá dramaturgická ambícia, invenčná poetická stratégia a postmoderná optika povyšujú na svojprávny žáner. Citlivo zvládnuté médium, zámerne balansujúce na klzkej hrane medzi umením a gýčom, medzi estetikou a pseudo-estétstvom, neodráža iba zmeny $\mathrm{v}$ oblasti umeleckej reprezentácie, ale predovšetkým reflektuje mocenský proces virtualizácie a alienácie samej reality, jej splývanie s vlastným deformovaným podobenstvom $\mathrm{v}$ obratne nastraženom zrkadle krvilačných médií. V dobe, ked' skutočnost' nahrádzajú hyperreálne simulakrá, ked' miznú tradičné kauzálne a referenčné rámce, ked’ sa funkcia spravodajských médií zúžila na navodzovanie zdania aktuálnosti, má čoraz viac l'udí vážne problémy odlíšit' skutočnost' od jej pragmaticky produkovaných fiktívnych surogátov. Zmätená hodnotová hierarchia l’udí potom o to úpornejšie lipne na osvedčených komunikačných stereotypoch, hlaadajúc $\mathrm{v}$ nich oporné barličky pre tápajúcu chôdzu $\mathrm{v}$ globalizovanom a zároveň dezintegrovanom svete. $\mathrm{V}$ tomto kontexte je nutné čítat' karaoke experiment trojice autorov Árií k nezaplacení.

A treba v ňom čítat' aj d’alší projekt združenia - spektakulárne predstavenie Fantom čili Krvavá opera (2005), kde kocha v role skladatel'a vystriedal Petr Kofron̆. Aj ono spája české operné dedičstvo s hermetickou tradíciou a čiernou mágiou a milo ironizuje inštitucionálny rámec. Autori tentoraz na pozadí beštiálneho príbehu rozpútali boj za pravý charakter Smetanovej Libuše, ktorý sa z ja- 
viska presunie do zákulisia inštitúcie a nejaviskových zákutí budovy divadla. Nad všetkým vládne trojjediný Fantóm (spevák, herec a kúzelník), načúvajúci odkazu legendárneho Herma Trismegista i magickým formulám Alesteira Crowleyho. Deklamované citácie zo Smaragdovej dosky, Kofroňove parafrázy Smetanovej hudby, iluzionistické exhibície kúzelníka Bušinu, árie z Libuše, herecké a baletné akcie, videoprojekcia citujúca z kultového filmu Fantóm opery, desivý zbor Husitov pri základných kameňoch ND, to všetko možno vidiet' a počut' v novodobom intermédiu.

„Opera nikdy nebola $v$ zhode s dobou - od samých svojich začiatkov bola pokladaná za čosi zastaralé, za retroaktívne riešenie nejakej vnútornej krizy $v$ hudbe a za nečisté umenie. Povedané hegelovsky, opera je zastaralá už v samom svojom pojme. Ako ju potom niekto nemôže mat' rád?" Týmito slovami sa nás Slavoj Žižek s Mladenom Dolarom snažia presviedčit, ${ }^{2}$ že opera je bytostne odsúdená na dobovú neaktuálnost'. Ale operné umenie nikdy nebolo izolované od spoločenskej reality. Do izolácie ho občas dostávali iba tí, čo nepochopili nadčasovost' posolstva mytologických tém a nevyhnutnost' vývoja symbolických foriem, vrátane umeleckých. Teda tí, čo sa dodnes snažia urobit' z opery mocenskú inštitúciu, zneužívajúcu král'ovský žáner na neumelecké (resp. pseudoumelecké ciele). Tento problém je vo svete dávno predmetom serióznej vedeckej debaty, ktorá splodila množstvo podnetných štúdií s metodologickými východiskami, siahajúcimi od psychoanalytických cez štrukturalistické až po postštrukturalistické a feministické. Debate, samozrejme, predchádzali mnohé odvážne operné produkcie, experimentujúce s tradičnými formami a testujúce únosnost' aktuálnych a aktualizovaných posolstiev.

Nová skúsenost's technológiou a médiami si vyžiadala novú senzibilitu a ponúka nové druhy estetického zážitku. Filozofi a estetici boli na prahu nového milénia nútení prehodnotit' pojem aisthesis a vrátili mu pôvodnú baumgartenovskú konotáciu zmyslového vnímania. Toho vnímania, ktoré svojho času hudobný kritik a estetik Eduard Hanslick nazval patologickým a degradoval ho na biologickú úroveň tvorby chloroformu. Estetika dnes integruje estetické s anestetickým; prvý aspekt zdôrazňuje vnímanie (zmyslové i kognitívne), druhý tematizuje necitlivost'. Všetkoprestupujúci proces estetizácie sa totiž v postmodernej spoločnosti paradoxne zmenil na svoj anestetizačný opak. Na jednej strane za to môže mediálna distribúcia falošnej krásy módnych trendov, na druhej strane naša obsesia „estetizovat" všetky aspekty života a prostredia. Redundancia pseudoestetična vedie $\mathrm{k}$ rapídnej devalvácii skutočného estetična, $\mathrm{k}$ baudrillardovskej pornografii. A umenie na tento neutešený stav prirodzene reaguje. „Umenie dnes,“ apelovala Susan Sontagová už pred štyridsiatimi rokmi (!), ,je nový druh nástroja, nástroja určeného na modifikáciu vedomia a organizáciu nových modov senzibility. Prostriedky na umeleckú prax sa radikálne rozšírili. Umelci by sa naozaj mali stat',

2 V spoločnej knihe Opera's Second Death. New York/Londýn: Routledge, 2002. 
ak majú reagovat' na túto novú funkciu [...], estetikmi seba-vedomia: neustále by mali spochybňovat' svoje prostriedky, materiály a metódy. “3

Vývoj umenia síce postupuje po iných krivkách než vedecký a technologický pokrok, aj ono sa však snaží držat' krok s rýchlo pulzujúcou dobou. Odl'ahčená forma, parafrázy, skratky a hyperboly v opernej poetike síce mnohých poburujú, no poburujú iba tých, ktorí nepostrehli (alebo zámerne ignorujú) novú funkciu umenia v informačnom veku. Ved' umenie sa už dávno zrieklo mimetických konvencií, popretŕhalo zväzujúce putá s predmetnou realitou a rezignovalo aj na metafyzické spôsoby reflexie sveta či dokonca mesiánske ambície. Už v ranom období modernizmu sústredilo pozornost' na vlastný jazyk, akcentujúc jeho nediskurzívne špecifiká, aby v postmodernom štádiu svojho vývoja rozšírilo túto orientáciu o poznanie neexistencie univerzálneho jazyka, uhla pohl'adu či kritéria. Dôslednou „babylonizáciou“ naočkovalo dokonca aj diskurz filozofie a humanitných vied, ktorý sa značne estetizoval a začal sa vyžívat' v intermediálnych presahoch.

Operné intermédiá, ktoré kedysi splodila renesančná túžba resuscitovat' antickú drámu, sa podl'a mnohých autorov ocitli v minulom storočí v kríze, podl’a niektorých dokonca umreli. Väčšina kuvičích ohlasovatel'ov smrti opery dogmaticky zatvára oči a zapcháva si uši pred inováciami v opernom umení, ich unáhlený verdikt však nemá nič spoločné s dôslednost'ou barthesovskej diagnostiky smrti autora. Postoje staromilských ohliadačov mŕtvol pripomínajú skôr zúfalé počínanie opitého Nekrocára z Ligetiho opernej frašky Le Grand Macabre (1975-77), ktorý sa, potom čo zistí, že neprivodil vytúžený zánik sveta, so slovami „Takže ... vy žijete ...“ rozplynie do fantómového prízraku. Sám projekt rekonštrukcie antickej tragédie prostredníctvom stile rappresentativo (či stile espressivo) na prelome 16. a 17. storočia nevyznieval príliš presvedčivo. Nová scénická forma svojou programovou orientáciou na idealizovanú minulost' totiž nemohla vhodne reprezentovat' novú paradigmu vedenia ani nový model spoločnosti, tej však nič nebránilo v tom, aby ju od začiatku uchopila mocensky. Raná opera síce už nebola obetným rituálom ani katarzným (inter)médiom, no ani reprezentačné poslanie neplnila dôkladne, a ked', tak iba krátko. Čoskoro ju stihol osud attaliovských repetící - namiesto toho, aby upevňovala vieru vo vládnucu ideológiu, začala slúžit' elitárskej zábave a neskôr, snád' ešte viac než iné umenia, podlahla štylizovanému manierizmu, narcizmu, snobskému elitárstvu i účelovej komodifikácii. Wagner síce vniesol do operného umenia dionýzovské (alebo, podl'a Kanta, dynamické) vznešené, no jeho rozhodnutie „zničit' existujúci rád vecí" stroskotalo - v ideologickej, filozofickej i esteticko-umeleckej rovine na deštruktívnom revolucionizme s koreňmi v antihistoristickej a antietatistickej doktríne, na idealistickom až utopickom presvedčení o prekonatel'nosti kozmického teleologizmu fylogenetickou rekonštrukciou l'udského druhu, na svojsky interpretovanom schopenhauerovskom mysticizme, mesiášskom vizionárstve 
(Zukunftsmusik a Kunstwerk der Zukunft), neskororomantickej remytologizácii a pofidérnom estétstve.

A tak, k d'alšiemu zmítvychvstaniu opery došlo až koncom 20. storočia, ked' modernistické praktiky radikálne zmenili tvár umenia a rozrušili hierarchické štruktúry $\mathrm{v}$ jeho prezentácii a reflexii. Neobišli ani konzervatívne operné inštitúcie. Nová opera sa však tentoraz neznovuzrodila z kontextových reinterpretácií mýtov, ale paradoxne z formálnych repetícií - štruktúrnych i technologických. John Cage koncipoval všetky svoje Europery výlučne z fragmentov historických opier, pričom niektoré vokálne party reprodukoval z gramofónov a pásu. Demontoval tak autora a ocitol sa v úlohe Barthesovho pisatel'a, ktorému neostáva „nič iné než imitovat' predchádzajúce, nikdy nie pôvodné gesto“ a „premiešavat' jednotlivé písania, vzájomne ich konfrontovat', aby nenachádzal t'ažisko na žiadnom z nich." ${ }^{4}$ A Philip Glass s Robertom Wilsonom v scénickom multimédiu Einstein on the Beach (1976) či Robert Ashley v televíznej opere Perfect Lives (1979-1983) už ani nerecyklujú, iba opakujú hlasy a gestá, ktoré akoby nikdy nepatrili žiadnemu subjektu. Multimediálne elaboráty repetící́, ako môžeme ich diela smelo nazvat', postupujú ireverzibilne v lineárnom, diachronickom slede bez hierarchických ambícií, a to aj vtedy, ked’ sa opierajú o naratívne štruktúry. Ich autori sa niekedy vyžívajú v expresívnom gradovaní, inokedy uprednostňujú minimalistickú striedmost', v obidvoch prípadoch je však cítit' ako postindustriálna doba degradovala „humánne“ stroje na ničenie času (lévi-straussovské mýtické a hudobné formy) na odosobnené automaty. A tak sme sa nakoniec dožili aj opier bez l'udského hlasu, kde sú spevácke party - generované elektronicky alebo imitované mechanicky - nahradené technologickými simulakrami. No ani umlčanie l'udského hlasu vo vel'kej symbolickej forme, ktorá si vždy potrpela na spevácku exhibíciu, ešte nemusí znamenat' jej zánik. Ved’ aj legendárny Orfeov hlas, viacnásobnou resuscitáciou ktorého vznikla európska opera, spieval aj potom, čo bol násilne oddelený od tela jeho nositel’a, čo dnes napokon, vd’aka teleprezentácii a telematickej simulácii, nie je neuskutočnitel'né.

Prevratné zmeny v umeleckom myslení narážajú pochopitel'ne na rezistenciu zástancov etablovaných konvencií. Mnohé operné predstavenia posledných desat'ročí skutočne nespĺn̆ajú formálne kritériá ortodoxného žánru, no tie kedysi nesplńal ani Wagnerov Gesamtkunstwerk. To ale neznamená, že súčasná opera nedokáže zmysluplne reflektovat' rozptýlenú a unikajúcu realitu, generovat' estetické zážitky a že nestojí za serióznejšiu reflexiu. Možno by sme jej zatracovatel'om pomohli prekonat' averziu voči nej, keby sme ju jednoducho nenazývali operou. To by však bolo rovnako neproduktívne riešenie, ako nazývat' hudbu po Cageovi sound artom. O to viac, že pre otvorené umelecké dielo, akým mnohé súčasné javiskové multimédiá nesporne sú, sa vžil nádherný pojem opera aperta. 
Jozef Cseres přednáší estetiku a filozofii umění na Filozofické fakultě UK v Bratislavě a Filozofické fakultě MU v Brně. Předmětem jeho vědeckého zájmu jsou strukturální vztahy mezi hudbou a mýtem, umělecká reprezentace a interpretace, experimentální a improvizovaná hudba a intermedia.

\begin{abstract}
:
The paper deals with two opera performances of the Střežený Parnass ${ }^{\mathrm{TM}}$ (Guarded Parnassus ${ }^{\mathrm{TM}}$ ) art group from Brno - Arias That Money Cannot Buy (2002) and Phantom or Bloody Opera (2005). These two stage works, commissioned for the National Theatre in Prague, provoked quite controversial reactions because of loosened postmodern poetics to which the Czech opera visitors and critics are still not accustomed. Treating both performances in a global context of current operamaking, I intend to emphasize the transformations the opera genre and its cultural reflection undergone in world during last decades.
\end{abstract}

\title{
Key words:
}

intermedium, multimedium, myth, mytheme, opera, poetics, representation, technology

\section{Bibliography:}

BARTHES, Roland. Mytologie. Praha: Dokořán, 2004.

BARTHES, Roland. Smrt' autora. In Profil súčasného výtvarného umenia. 2001, č. 1-2, s. 11.

SONTAG, Susan. One Culture and the New Sensibility. In Against Interpretation. New York: Anchor Books, 1990.

ŽIŽEK, Slavoj - DOLAR, Mladen. Opera’s Second Death. New York/Londýn: Routledge, 2002. 
